\title{
The impact of plant density and spatial arrangement on light interception on cotton crop and seed cotton yield: an overview
}

\author{
CHAPEPA Blessing $^{1 *}$, MUDADA Nhamo $^{2}$ and MAPURANGA Rangarirai ${ }^{3}$
}

\begin{abstract}
Light attenuation within a row of crops such as cotton is influenced by canopy architecture, which is defined by size, shape and orientation of shoot components. Level of light interception causes an array of morpho-anatomical, physiological and biochemical changes. Physiological determinants of growth include light interception, light use efficiency, dry matter accumulation, duration of growth and dry matter partitioning. Maximum light utilization in cotton production can be attained by adopting cultural practices that yields optimum plant populations as they affect canopy arrangement by modifying the plant canopy components. This paper highlights the extent to which spatial arrangement and density affect light interception in cotton crops. The cotton crop branches tend to grow into the inter-row space to avoid shade. The modification of canopy components suggests a shade avoidance and competition for light. Maximum leaf area index is obtained especially at flowering stage with higher populations which depicts better yields in cotton production.
\end{abstract}

Keywords: Light interception, Plant populations, Spatial arrangement, Canopy architecture

\section{Introduction}

Plants contain the green pigment chlorophyll and they require light energy from the sun to photosynthesize and to grow. Light attenuation is an important aspect that influences the overall photosynthetic rate and the accumulation of biomass of plants, particularly cotton (Gossypium hirsutum L.). Thus light quality and light duration play an important role in the productivity of cotton. Cotton is a kind of sun-loving crop that requires many cloudless days to accumulate maximum biomass which translates to high productivity. The crop normally has regular shaped leaves (except for the okra leaf varieties) that are diaheliotropic (Sassenrath-Cole 1995; Zhang et al. 2009). According to Turitzin (1978) and

\footnotetext{
* Correspondence: bchapepa@gmail.com

${ }^{1}$ Department of Research and Specialist Services, Cotton Research Institute, P. Bag 765, Kadoma, Zimbabwe

Full list of author information is available at the end of the article
}

Bai et al. (2016), the extent and pattern of attenuation are determined by the architecture of the canopy and cotton with columnar-type canopies exhibits an open structure and it tends to grow into the inter-row space which allows it to intercept more irradiance moving down the crop canopy. This has a bearing on the flux density which is dependent on the orientation of leaves within the canopy, the rate of photosynthesis will be below its maximum value if the flux density is below the saturation level.

Light which occurs in the form of the wavelengths of electromagnetic radiation, is visible to the human eye in the range of approximately $380-770 \mathrm{~nm}$ and plants use the light in the wavelength of $400-700 \mathrm{~nm}$ for photosynthesis which is referred to as photosynthetically active radiation (PAR). Interception of solar irradiance by a crop canopy is a function of leaf area index (LAI), absorption, reflection, and transmission

(c) The Author(s). 2020 Open Access This article is licensed under a Creative Commons Attribution 4.0 International License, which permits use, sharing, adaptation, distribution and reproduction in any medium or format, as long as you give appropriate credit to the original author(s) and the source, provide a link to the Creative Commons licence, and indicate if changes were made. The images or other third party material in this article are included in the article's Creative Commons licence, unless indicated otherwise in a credit line to the material. If material is not included in the article's Creative Commons licence and your intended use is not permitted by statutory regulation or exceeds the permitted use, you will need to obtain permission directly from the copyright holder. To view a copy of this licence, visit http://creativecommons.org/licenses/by/4.0/. 
spectra of the component leaves and arrangement of leaves in the crop canopy (Campillo et al. 2012). Absorption of the light is one of the major determinants of crop yields apart from other factors like nutrient use efficiency, water use efficiency and crop duration. The deterioration of light environment in the lower part of the canopy due to heavy upper canopy foliage and small leaf area of the subtending leaves, has been associated with low source-to-sink interaction of assimilates which limits yield of lower bolls (Kerby et al. 1993; Niinemets 2007, 2016). Levels of PAR in high density plant populations of cotton have been shown to be low in lower parts of the canopy due to decreasing ratio of red: farred light provides energy for photosynthesis whilst lower population densities also resulted in lower light interception as most of the light was lost to the ground and thus resulted in lower productivity (Guinn 1974, as cited by Constable 1994). According to Gwiranenzara et al. (2014), a spacing of $0.7 \mathrm{~m} \times 0.2 \mathrm{~m}$ gave a higher seed cotton yield compared with wider spacing of 1 $\mathrm{m} \times 0.3 \mathrm{~m}$ suggesting full light utilization due to better light interception.

The leaf orientation substantially affects penetration of light into the plant canopies. Horizontal leaves will cause a decrease in irradiance whilst vertical leaves allow deeper penetration of light into the canopy, thus determining the net canopy photosynthesis. Song et al. (2013) suggested that the exponential extinction of light down the canopy below a given leaf area index is a function of the transmission coefficient of the leaf taking into account the light reflected down into the canopy by leaf surfaces, their absorptive, transmittance and reflectivity capabilities. With an ideal leaf arrangement, twice as much leaf area is required to intercept all incident light with a leaf angle of 60 degrees than if the leaf with angle of zero degree. In general terms, if leaf area index is constant, then the canopy interception will decrease as the leaf angle increases. Plant spaces affect the spectral distribution of the transmitted irradiance. For instance, in maize (Kasperbauer and Karlen 1994), the proportion of photons in PAR is less, and the photons of near infrared are more in closely spaced plants than in widely spaced plants. According to Dauzat et al. (2008), cotton showed a marked plasticity under various densities which affects light quality moving down the canopy.

Following evidence shows that photosynthesis is the major limiting factor in yield of cotton. Even when the plants are grown under maximum growing conditions, considerable efforts have been done on ways to improve the efficiency of the canopy for light interception and gaseous exchange (Guinn et al. 1976, as cited by Constable 1994; Morales et al. 2020). The management and genetic strategies of altering plant architecture and plant densities of cotton to improve light penetration into the canopy which may increase crop yields were suggested. These are cultural practices that yield optimum plant populations which affect canopy arrangement by modifying the plant canopy components so as to ensure maximum light attenuation into the plant canopy. Selection of varieties with a good geometry and leaf structure is important, because it determines the behaviour of the cotton plants in different spatial arrangements as influenced by plant spacing adopted by the farmers.

\section{Canopy architecture and light interception}

The spatial distribution of photosynthetic organs within a plant is referred to the canopy architecture and it varies greatly from species to species (Barthélémy and Caraglio 2007). This has a significant bearing on the ability of light to enter the canopy and influence on the rate of photosynthesis (Song et al. 2013). According to Lieffers et al. (1999), the availability of light within a plant canopy differs from about 20 to 50 fold from top to bottom within a closed canopy. This is due to a number of different factors like leaf orientation, shape, spatial arrangement, sun elevation, and changes in spectral distribution of the photosynthetic photon flux density (PPFD) within the plant canopy (Nobel et al. 1993; Murchie and Reynolds 2013). In a crop like cotton, there are two major types of canopies, the open canopy and closed canopy (Reta-Sánchez and Fowlerb 2002). These canopies are directly linked to the leaf shape and structure; the mutant deeply divided okra shaped leaf allows for an open structure and a weakly divided or normal leaf type provides a closed structure for the plants. These two different canopies affect the interception of light differently and influence the overall yield. The use of okra-leaf or sub-okra-leaf allowed competitive or higher yields compared with normal leaf types to be obtained (Meredith 1984; Wells et al. 1986). According to Gonias et al. (2011), values of radiation use efficiency were estimated at 1.897 and $2.636 \mathrm{~g} \cdot \mathrm{MJ}^{-1}$ of intercepted photosynthetically active radiation for the normal- and okra-leaf types, respectively. This clearly indicated the importance of canopies that allow solar radiation penetration. Development of lower cotton bolls depends primarily on adjacent leaves (Kerby et al. 1980) and openness of the leaves, which permit light penetration to lower leaves. The okra-shaped leaf varieties allow more interception of light by the lower leaves (Zhu et al. 2008). The early closure of rows and excessive vegetative growth above developing fruiting branches usually cause less penetration of sunlight into the canopy and, consequently, cause an increase in the abscission of fruiting forms and a decrease in fibre quality (Kerby and Ruppenicker 1992; Kerby et al. 1993), presumably due to the lack of assimilates being synthesized by the shaded leaves. There was a $40 \%$ less foliage at maturity than 
normal leaf cotton types which permitted $70 \%$ more light into the canopy of cotton (Andries et al. 1969, as cited by Thaxton and El-Zik 1994).

A canopy with more erect leaves (erectophile) will require a $60 \%$ greater LAI to absorb the same amount of PPFD (Valladares and Niinemets 2007). An erectophile canopy will absorb less PPFD than planophile canopy (i.e., a canopy with horizontal leaves) when the LAI is relatively low. However, differences in PPFD absorption between the two kinds of canopies reduce at high LAI (Struik et al. 2001). A canopy with more erect leaves will distribute the absorbed PPFD across a larger sunlit leaf area, resulting in a lower absorbed PPFD per unit sunlit leaf area. Canopy photosynthesis will be greater in erectophile than in planophile canopies when PPFD absorption is similar for the two kinds of canopies, because photosynthetic efficiency (i.e., photosynthesis per unit absorbed PPFD) is greater at low than at high PPFD (Falster and Westoby 2003; Du et al. 2017). Studies that were done on cotton in Zimbabwe have not dwelt much in the effect of canopy structure on light interception. A number of cases where canopy and light were discussed, only gave theoretical assumptions on the interaction between the canopy structure and light interception (Cotton Research Institute Annual Report 2011, unpublished).

\section{Plant densities and light interception}

Plant population density alters leaf azimuthal distribution. It also influences plant sizes. Appropriate plant density is an important crop management practice that can optimise canopy light distribution and increase canopy photosynthetic capacity in cotton (Yao et al. 2016). In studies done in 1975-76 and 2006-07 (Cotton Research Institute Annual Report 1976, 2007, unpublished), on the effect of different cotton spacings on yields and components of seed cotton, it was found that there was a general trend that densely populated cotton crop have more yield than sparsely populated plants. In general, highly populated plants have a tendency of closing the ground faster than sparsely populated plants and thus optimum leaf area index is normally reached faster in the densely populated crops as compared with sparsely populated crops. As the plant develops, assimilates supply increases asymptomatically as leaf areas increase (Hearn 1994; Xie et al. 2018). Increasing the population of cotton crops generally increased the LAI until such a population when any further increase in population and LAI had no effect on improving yield.

Planting pattern impacts on the equilibrium constant $(K c)$ values for crops grown at plant densities that do not reach the maximum ground leaf area index. Under these conditions, a more even plant distribution pattern will be useful for maximizing light attenuation during critical stages of fruit development (Maddoni et al.
2001). Plant densities and other cultural practices aimed at improving light interception (population, row spacing) affect plant canopy architecture by modifying shoot components like leaf size, orientation and insertion in the stock and senescence of older lower leaves. In 197576 season, a trial conducted at Cotton Research Institute, Zimbabwe, on canopy modification indicated that removal of main stem leaf did not lead to an improved yield as was theorized that open plant structure would assist in the development of bolls positioned in the lower canopy. Gono (1995) found out that the yield of sorghum depending on season in Esigodini, Ntabazinduna and Gutu increased with the increase of plant population. In Australia, increasing plant densities increased LAI (Fischer and Wilson, as cited by Gono 1995). Plant density highly influenced light extinction coefficients $(K)$ for main stem leaves when measured at their natural angle of display, when growth and light receipt by main stem cotton leaves in relation to plant density in the field were studied (Constable and Title 1986). For plant densities of 2,8 and $24 \mathrm{~m}^{-2}, K$ values were $3.56 \pm 0.26$, $1.76 \pm 0.08$ and $1.15 \pm 0.10$, respectively (Constable and Title 1986). These effects were attributed to the more "clumpy" nature of plants at lower densities. When measured at ground level with a linear sensor held horizontally under a medium plant density crop, $K$ value was $0.87 \pm 0.03$ (Constable and Title 1986).

Plant densities effectiveness depends on the increase of LAI to the optimum LAI and increase in aboveground dry matter with any further increase resulting in no major impact on yield of cotton (Su et al. 2015). Increasing leaf area is coupled with increased light interception for most crop canopies thus efficiently using radiation energy, and closely packed canopy generally has lower numbers of light specks compared with open canopies, especially on the cotton varieties with shallowly divided leaves.

\section{Spatial arrangements and light interception}

In a study done at Cotton Research Institute in Zimbabwe, close spacing was found to give rise to a quicker formation of a closed canopy, a larger number of fruiting points per acre, fewer and less well developed monopodia (vegetative braches) and quicker maturity. Higher rate of development of a closed canopy suggested an increased rate of LAI and hence an increased rate of photosynthesis (Cotton Research Institute Annual Report 2007, unpublished). High LAI had been recorded in narrow rows than wider rows (Lunagaria and Shekh 2006) where investigation was undertaken to study the effect of row orientation and row spacing on radiation interception, LAI and light extinction coefficient of wheat crop (Triticum aestivum L.) in arid conditions. Increasing populations of crop willincrease LAI, providing 
maximum economic yield up to the optimum LAI. Further increase of LAI, through population manipulation may not improve economic yields, i.e., optimum plant populations would have been reached.

Meredith (1984) compared the influence of mutant leaf types, okra, super okra and sub okra (deeply divided leaves) shapes to normal (very shallowly divided leaves) leaf type cotton on lint yield, and then found out that the open canopy cottons of okra shaped leaf types permitted greater light penetration and air movements into the lower parts of the canopy than does normal leaf cotton. Thus, increasing the densities of the mutant okra leaf cottons would result in an increase of LAI which should in turn give rise to more yields than increasing the densities of normal leaf shaped cottons. The challenge in spatial arrangements of leaves on canopies and of cotton plants on the ground is to balance for effectively intercepting light, and yet, also, opening the canopy allows greater gaseous exchange and lower humidity below the canopy. Employment of mutant leaf types that allows more light to reach each leaf within the canopy (Constable 1994) could be more ideal in cotton production. According to Andres et al. (2016), an ideal cotton cultivar would produce normal leaves up until the point canopy closure is obtained and then switch over to an open canopy of okra or super okra. This was shown to have benefits of full lower boll maturation and increase in size. Guinn (1974) in Constable (1994) indicated that levels of PAR reaching the lower part of the plant canopy in high density populations of cotton might be severely limiting photosynthesis. Developing bolls get most of the photosynthetic assimilates from the subtending leaves, bracts and leaves one node above or below them (Ashley 1972, as cited by Constable 1994). This therefore means that more light should penetrate the canopy, so that the bolls under the canopy can be well fed.

It would be ideal for cotton breeders and agronomists to breed cotton varieties with canopies allowing more light to reach further into deeper layers of the plant canopy, and allowing rapid early season development of LAI to effectively reduce the amount of solar radiation that reaches the soil (Constable 1994; Andres 2016).

\section{Offers done to improve the leaf area index of crops to optimum levels in Zimbabwe and other countries}

All agronomic practices (including spacing and population densities) result in crop canopy modification and changes of leaf area index. The use of balanced nutrients, moisture and growth regulators like Gibberellins to improve growth is important to improve leaf area index of crops. Opportunities for improving photosynthesis performance of crops also exist (Chrispeels and Sadava
2003) through increasing the photosynthetically available light spectrum and implementing $\mathrm{C} 4$ photosynthesis to C3 plants (Éva et al. 2018). The distribution of light among leaves can be altered. With the sun overhead, PAR intercepted per unit leaf by horizontal leaf canopy on the top of the canopy is $900 \mathrm{~J} \cdot \mathrm{m}^{-2} \cdot \mathrm{s}^{-1}$, i.e., three times the amount required to saturate photosynthesis (Lieffers et al. 1999). In this scenario, two-thirds of the light intercepted is wasted. The best scenario would be a situation where less light is intercepted at the top of the canopy giving room for more light to penetrate the canopy to reach lower leaves. The most ideal situation will be plant ideotype with 75 degrees angle at the top and thus $300 \mathrm{~J} \cdot \mathrm{m}^{-2} \cdot \mathrm{s}^{-1}$ energy will be absorbed and then the remaining direct light of $600 \mathrm{KJ}$ will penetrate the canopy for use by leaves and photosynthesizing structures under the canopy. At the middle and as we decent down the plant canopy, the leaves must be nearing horizontal as such an arrangement will spread the radiation energy more evenly between layers of leaves within the canopies (Rosati et al. 2004). In general, uppermost leaves must be more vertical and the lowermost leaves must be horizontal (Long et al. 2006).

Modification of plant with model characteristics known to influence photosynthesis, growth and grain production was introduced by Donald in 1968 as cited by Mayo (1987). Thus, breeders aimed at having a type of cotton plants with conical canopy as compared with bushy types of canopies for improved light penetration. High LAI is the key to achieve high photosynthetic rates. A LAI of eight has been found to enhance maximum total above ground yield of some crop plants. Studies with mutant okra shaped cotton plants indicated that dwarf small and erect leaves had higher economic yield than the plants with big leaves (Andres 2016). It is therefore in the interest of yield to produce cotton plants with open canopies as in okra shaped crops where more light penetrates the canopies than the normal shaped okra cottons.

Studies of various canopy manipulations on their effect on seed cotton yield indicated that total seed cotton yield tended to be improved by light penetration and ventilation into the lower levels of the canopy (Rabey 1978; Kaggwa-Asiimwe et al. 2013; Zhi et al. 2014). Studies on the use of crop growth regulators like PGRIV and Mepiquat chloride were conducted to find their effect on productivity of cotton which has perennial growth habit that causes difficulties in maintaining control of vegetative growth, especially under high nitrogen fertility and irrigation regimes (Bourland and Watson Jr. 1990). Mepiquat chloride was found to increase gross canopy photosynthesis and promote development of thicker leaves with reduced leaf surface area. The use of growth regulators in cotton has been found to reduce 
height and leaf area index to desirable levels. Thus, instead of development of high leaf area, more assimilates were channelled towards reproductive structures than vegetative growth structures. Breeders must aim to improve the light interception within a cotton crop canopy by altering the leaf morphology. This has given rise to high plant populations in cotton production in China, which have been found to enhance economic yields in drier regions of this country.

Mutant super okra, okra and semi- or sub-okra leaf types differed in their light interception capacities within canopies. New varieties of cotton in Zimbabwe, namely CRI MS 1, CRI MS 2 and an earlier variety, LS 9219, have also been bred with such characteristics where upper leaves tend to be erectophile than planophile structure. These have evenly spaced leaves and an open canopy that allows more light penetration and air circulation (Anonymous 1 n.d.).

\section{Conclusion}

Plant density and spatial arrangements affect the efficiency of light interception by cotton crop canopies. Leaf shape affects the amount of light intercepted in cotton with mutant deeply divided okra shaped leaves having higher light interception in canopies than shallowly divided normal leaves. When maximum ground LAI reached, light attenuation do not vary across different row spacings in crop production. Planting cotton in rows results in the crop subtending its vegetative branches more into the inter-row spaces than the in-row spaces. More light is intercepted in higher plant densities. This has a tremendous effect on seed cotton yield and is the approach that needs to be adopted in all cotton production systems.

\section{Acknowledgments}

Not applicable.

\section{Authors' contributions}

Chapepa B developed the main manuscript with Mudada N providing the insight of research on cotton densities and cotton breeding strategies to improve light interception. Mapuranga R provided information on canopy architecture and light interception. The author(s) read and approved the final manuscript.

\section{Author's information}

Nil

\section{Funding}

Source of funding for compiling this review paper is the Department of Research and Specialist Services through the Cotton Research Institute, Zimbabwe.

Availability of data and materials

Not applicable.

Ethics approval and consent to participate

Not applicable.
Consent for publication

Not applicable.

\section{Competing interests}

The authors declare that they have no competing interests.

\section{Author details}

${ }^{1}$ Department of Research and Specialist Services, Cotton Research Institute, P. Bag 765, Kadoma, Zimbabwe. ${ }^{2}$ Department of Research and Specialist Services, Plant Quarantine Services Institute, Mazowe, Zimbabwe. ${ }^{3}$ Epoch Mine Campus, Gwanda State University, P. O. Box 30, Filabusi, Zimbabwe.

Received: 26 February 2020 Accepted: 22 June 2020

Published online: 27 July 2020

\section{References}

Andres RJ, Bowman DT, Jones DC, Kuraparthy V. Major leaf shapes of cotton: genetics and agronomic effects in crop production. J Cotton Sci. 2016;20(4): $330-40$.

Anonymous 1. Cotton seed distributors limited, NPO box 117, Wee Waa Australia. n.d.

Bai Z, Mao S, Han Y, et al. Study on light interception and biomass production of different cotton cultivars. PLoS One. 2016;11(5):e0156335. https://doi.org/10. 1371/journal.pone.0156335

Barthélémy D, Caraglio Y. Plant architecture: a dynamic, multilevel and comprehensive approach to plant form, structure and ontogeny. Ann Bot. 2007;99:375-407. https://doi.org/10.1093/aob/mcl260 .

Bourland FM, Watson CE Jr. COTMAP, a technique for evaluating structures and yield of cotton plants. Crop Sci. 1990;30:224-6. https://doi.org/10.2135/ cropsci1990.0011183X003000010048X.

Campillo C, Fortes R, del Henar Prieto M. Solar radiation effect on crop production solar radiation. In: Babatunde EB, editor. Solar radiation. In Tech (Open Access); 2012. https://doi.org/10.5772/34796

Chrispeels MJ, Sadava DE. Plants genes and crop biotechnology. 2nd ed. Boston: Jones and Bartlett Publishers, in partnership with the American Society of Plant Biologists and the ASPB Education Foundation; 2003.

Constable GA. Predicting yield responses of cotton to growth regulators. In: Constable GA, Forrester NW, editors. Challenging the futures: proceedings of the world cotton research conference 1. Clayton: CSIRO Publishing; 1994. p. $3-5$

Constable GA. Growth and light receipt by main stem cotton leaves in relation to plant density in the field. Agric For Meteorol. 1986;37(4):272-92. https:// doi.org/10.1016/0168-1923(86)90066-3.

Cotton Research Institute. Cotton Research Institute Annual Report. Department of Research and Specialist Services, P. Bag 765, Kadoma, Zimbabwe. 2011.

Cotton Research Insitiute. Cotton Research Insitiute Annual Report. Department of Research and Specialist Services, P. Bag 765, Kadoma, Zimbabwe. 1976.

Cotton Research Insitiute. Cotton Resaerch Insitute Annul Report. Department of Research and Specialist Services, P. Bag 765, Kadoma, Zimbabwe. 2007.

Dauzat J, Clouvel P, Luquet D, Martin P. Using virtual plants to analyse the lightforaging efficiency of a low-density cotton crop. Ann Bot. 2008;101(8):115366. https://doi.org/10.1093/aob/mcm316.

Du S, Liu L, Liu X, Hu J. Response of canopy solar-induced chlorophyll fluorescence to the absorbed photosynthetically active radiation absorbed by chlorophyll. Remote Sens. 2017;9(9):911. https://doi.org/10.3390/ rs9090911.

Éva C, Oszvald M, Tamás L. Current and possible approaches for improving photosynthetic efficiency. Plant Sci. 2019;280:433-40. https://doi.org/10. 1016/jplantsci.2018.11.010.

Falster DS, Westoby M. Leaf size and angle vary widely across species: what consequences for light interception? New Phytol. 2003;158:509-25. https://doi.org/10.1046/j.1469-8137.2003.00765.x.

Gonias ED, Oosterhuis DM, Bibi AC. Light interception and radiation use efficiency of okra and normal leaf cotton isolines. Environ Exp Bot. 2011;72(2): 217-22. https://doi.org/10.1016/j.envexpbot.2011.03.008 .

Gono TL. A relook at the current fertilizer and plant population recommendations for grain sorghum in the communal areas of Zimbabwe. In: Twomlow S, Ellis-Jones J, Hagmann J, Loos H, editors. Soil and water conservation for smallholders farmers in semi-arid Zimbabwe, transfers between research and extension, Proceedings of a technical workshop, 3-7 April 1995. Masvingo: Belmont Press; 1995. 
Gwiranenzara C, Chapepa B, Mubvekeri W. Effect of plant manipulation and plant density on seed cotton yield. Zimbabwe: Cotton Research Institute 2014 Annual report, Department of Research and Specialist Services; 2014.

Hearn AB. The principal of cotton water relations and their applications in management. In: Constable GA, Forrester NW, editors. Challenging the futures: proceedings of the world cotton research conference 1. Clayton: CSIRO Publishing; 1994. p. 66-92. http://hdl.handle.net/102.100.100/23343 0 ?index $=1$

Kaggwa-Asiimwe R, Andrade-Sanchez P, Wang G. Plant architecture influences growth and yield response of upland cotton to population density. Field Crop Res. 2013;145:52-9. https://doi.org/10.1016/j.fcr.2013.02.005.

Kasperbauer MJ, Karlen DL. Plant spacing and reflected far-red light effects on phytochrome-regulated photosynthate allocation in corn seedlings. Crop Sci. 1994;34:1564-9. https://doi.org/10.2135/cropsci1994.0011183X003400060027x.

Kerby TA, Buxton DR, Matsuda K. Carbon source-sink relationship within narrowrow cotton canopies. Crop Sci. 1980;20:208-13. https://doi.org/10.2135/ cropsci1980.0011183X002000020015x

Kerby TA, Keeley M, Watson M. Variation in fiber development as affected by source to sink relationships. In: Herber DJ, Richter DA, editors. Cotton physiology conference. Proc Beltwide Cotton Conf, New Orleans, LA. Memphis: National Cotton Council; 1993. p. 1248-51.

Kerby TA, Ruppenicker G. Canopy architecture and fiber quality variation by branch location. In: Herber DJ, Richter DA, editors. Cotton physiology conference. Proc beltwide cotton conf, Nashville, TN. Memphis: National Cotton Council; 1992. p. 1069

Long SP, Zhu XG, Naidu SL, ORT DR. Can improvement in photosynthesis increase crop yields? Plant Cell Environ. 2006;29:315-30. https://doi.org/10. 1111/j.1365-3040.2005.01493.x

Lunagaria MM, Shekh AM. Radiation interception, light extinction coefficient and leaf area index of wheat (Tritium Aestivum L.) crop as influenced by row orientation and row spacing. Anand: Department of Agricultural Meteorology, Anand Agricultural University; 2006.

Maddoni GA, Otegui ME, Cirilo AG. Plant population density and, row spacing and hybrid effects on maize canopy architecture and light attenuation. Field Crops Res. 2001;71:183-93.

Mayo O. The theory of plant breeding. 2nd edition. Oxford: Claredon Press; 1987.

Meredith WR. Influence of leaf morphology on lint yield on cotton enhancement by the sub okra trait. Crop Sci. 1984;24:855-7.

Morales F, Ancin M, Fakhet D, et al. Photosynthetic metabolism under stressful growth conditions as a bases for crop breeding and yield improvement. Plants. 2020;9(1):88. https://doi.org/10.3390/plants9010088 .

Murchie E, Reynolds M. Crop radiation capture and use efficiency. In: Christou P, Savin R, Costa-Pierce BA, et al, editors. Sustainable food production. New York: Springer; 2013. https://doi.org/10.1007/978-1-4614-5797-8

Niinemets Ü. Photosynthesis and resource distribution through plant canopies. Plant Cell Environ. 2007;30(9):1052-71. https://doi.org/10.1111/j.1365-3040. 2007.01683.x

Niinemets Ü. Leaf age dependent changes in within-canopy variation in leaf functional traits: a meta-analysis. J Plant Res. 2016;129(3):313-38. https://doi. org/10.1007/s10265-016-0815-2 .

Nobel P, Forseth I, Long S. Canopy structure and light interception. In: Hall D, Scurlock J, Bohlar-Nordenkampf $\mathrm{H}$, et al., editors. Photosynthesis and production in a changing environment: a field and laboratory manual. New York: Springer; 1993. p. 79-90.

Rabey GG. Agronomy and physiology, annual report, Cotton Research Institute, Department of Research and Specialist Services. Salisbury: R \& SS Information Services; 1978.

Reta-Sánchez DG, Fowlerb JL. Canopy light environment and yield of narrow-row cotton as affected by canopy architecture. Agron J. 2002;94:1317-23.

Rosati A, Metcalf SG, Lampinen BD. A simple method to estimate photosynthetic radiation use efficiency of canopies. Ann Bot. 2004;93(5):567-74. https://doi. org/10.1093/aob/mch081

Sassenrath-Cole GF. Dependence of canopy light distribution on leaf and canopy structure for two cotton (Gossypium) species. Agric For Meteorol. 1995;77(1): 55-72. https://doi.org/10.1016/0168-1923(95)02238-S.

Song Q, Zhang G, Zhu XG. Optimal crop canopy architecture to maximise canopy photosynthetic $\mathrm{CO}_{2}$ uptake under elevated $\mathrm{CO}_{2}-$ a theoretical study using a mechanistic model of canopy photosynthesis. Funct Plant Biol. 2013; 40:109-24. https://doi.org/10.1071/FP12056
Lieffers VJ, Messier C, Stadt KJ, et al. Predicting and managing light in the understory of boreal forests. Can J For Res. 1999;29:796-811. https://doi.org/ 10.1139/x98-165

Struik P, Nösberger J, Geiger HH. Crop science: progress and prospects. Wallingford: $C A B \mid ; 2001$.

Su L, Wang Q, Wang C, Shan Y. Simulation models of leaf area index and yield for cotton grown with different soil conditioners. PLoS ONE. 2015;10(11): e0141835. https://doi.org/10.1371/journal.pone.0141835.

Thaxton PM, El-Zik KM. Development of MAR cotton germplasm with morphological mutants' traits. In: Constable GA, Forrester NW, editors. Challenging the futures: proceedings of the world cotton research conference 1. Clayton: CSIRO Publishing; 1994. p. 244-50.

Turitzin SN. Canopy structure and potential light competition in two adjacent annual plant communities. Ecol Soc Am. 1978;59(1):161-7. https://doi.org/10. 2307/1936643

Valladares F, Niinemets $U$. The architecture of plant crowns: from design rules to light capture and performance. In: Pugnaire FI, Valladares F, editors. Functional plant ecology. New York: Taylor and Francis; 2007. p. 101-50. https://doi.org/10.1201/9781420007626.ch4 .

Wells R, Meredith WR Jr, Williford JR. Canopy photosynthesis and its relationship to plant productivity in near-isogenic cotton lines differing in leaf morphology. Plant Physiol. 1986;82:635-40. https://doi.org/10.1104/pp.82.3. 635

Xie T, Su P, Zhao W, Li S. Cluster planting impact on cotton growth, yield and biomass accumulation in an arid region oasis. Sci Cold Arid Regions. 2018; 10(3):271-8. https://doi.org/10.3724/SP.J.1226.2018.00271.

Yao H, Zhang Y, Yi X, et al. Cotton responds to different plant population densities by adjusting specific leaf area to optimize canopy photosynthetic use efficiency of light and nitrogen. Field Crop Res. 2016;188:10-6. https:// doi.org/10.1016/j.fcr.2016.01.012.

Zhang YL, Zhang ZH, Feng GY, et al. Leaf diaheliotropic movement can improve carbon gain and water use efficiency and not intensify photoinhibition in upland cotton (Gossypium hirsutum L.). Photosynthetica. 2009;47(4):609-15. https://doi.org/10.1007/s11099-009-0087-3

Zhi X, Han Y, Mao S, et al. Light spatial distribution in the canopy and crop development in cotton. PLoS One. 2014;9(11):e113409. https://doi.org/10. 1371/journal.pone.0113409

Zhu W, Liu K, Wang XD. Heterosis in yield, fiber quality, and photosynthesis of okra leaf oriented hybrid cotton (Gossypium hirsutum L.). Euphytica. 2008;164: 283-91. https://doi.org/10.1007/s10681-008-9732-3
Ready to submit your research? Choose BMC and benefit from:

- fast, convenient online submission

- thorough peer review by experienced researchers in your field

- rapid publication on acceptance

- support for research data, including large and complex data types

- gold Open Access which fosters wider collaboration and increased citations

- maximum visibility for your research: over $100 \mathrm{M}$ website views per year

At BMC, research is always in progress.

Learn more biomedcentral.com/submissions 